Bishop Henryk Ciereszko Archidiecezjalne Wyższe Seminarium Duchowne w Biatymstoku

\title{
Blessed Michael Sopocko: The Apostle of Divine Mercy
}

Fr. Michael Sopocko played a unique and exceptional role in the history of spreading the devotion to Divine Mercy in our times. As Jesus revealed to St. Faustina during her visions, Fr. Sopocko was chosen by Him to serve as St. Faustina's confessor and spiritual director. In the process, Fr Sopocko became open to the apostolate of Divine Mercy. Sr. Faustina considered Fr. Sopocko the co-creator and continuator of the mission entrusted to her to proclaim the truth about and spread devotion to Divine Mercy. Specifically, Fr. Sopocko was the one who told St. Faustina to keep her Diary, and he oversaw the painting of the first image of the Merciful Jesus in Vilnius in 1934. Initially, Fr. Sopocko began spreading devotion to Divine Mercy by writing about it. In 1937, he published the prayers of the Chaplet and Novena to Divine Mercy. He also sought to establish the Feast of Divine Mercy and to have devotion to Divine Mercy approved by the church authorities. In addition, he tirelessly taught the faithful about Divine Mercy and published a number of works devoted to this truth and devotion. His dedication, perseverance in difficulties, and apostolic zeal were undoubtedly indispensible in establishing the apostolate of Divine Mercy in our times and spreading the message of Divine Mercy in Poland and throughout the entire world.

Key words: Divine Mercy, Divine Mercy apostolate, devotion to Divine Mercy, St. Faustina Kowalska, Bl. Michael Sopocko.

As Sr. Faustina's confessor and spiritual director, co-organizer and continuator of her mission, and a tireless apostle of the truth of and devotion to Divine Mercy, Fr. Michael Sopocko played an exceptional role and has a unique place in the history of spreading the devotion to Divine Mercy in our times. 

Bl. Michael
Sopocko

Michael Sopocko was born on November 1, 1888 in northeastern

Poland, which had been enslaved for almost one hundred years. After a difficult journey to the priesthood due to his family's impoverishment and the difficulties that the tsarist administration posed, Fr. Sopocko was ordained in Vilnius in 1914. From 1914-1918, Fr. Sopocko served as the vicar of the parish of Taboryszki, and he served as a military chaplain both in Warsaw and in Vilnius from 1919-1932. At the beginning of the 1920s, Fr. Sopocko began studies at the University of Warsaw's Faculty of Theology and subsequently completed his doctorate in 1926. During that time, he also studied at the National Institute of Pedagogy. In 1927, Fr. Sopocko was hired by the Stefan Batory University (SBU) to work in its Faculty of Theology as the Chair of Pastoral Theology. He lectured at the university until it closed during World War II. In 1934, he obtained his postdoctoral degree (habilitation) from the University of Warsaw and was appointed Associate Professor in the Faculty of Theology of the SBU in Vilnius. From 1927-1932, Fr. Sopocko also served as the spiritual father for the students of the Metropolitan Seminary in Vilnius. In 1933, he became St. Faustina Kowalska's confessor and spiritual director and served her in this role until she died in 1938. Through the influence of St. Faustina's visions and revelations, Fr. Sopocko dedicated himself to spreading the truth and apostolate of devotion to Divine Mercy until the end of his life. During World War II and the German occupation of Poland, Fr. Sopocko went into hiding in order to escape being arrested by the Germans. He ministered in Vilnius until 1947, when he moved to Bialystok and served as a professor at the seminary there. In 1962, Fr. Sopocko retired and served as a priest for a number of years in the chapel located at ul. Poleska until he died in the opinion of holiness on February 15, 1975. He was beatified in Bialystok in 2008.

The short biographical sketch of Fr. Sopocko above conveys only the stages of his life and not the greatness of his works, the uniqueness and eminence of his character, nor his rich spiritual life. He had an extraordinary personality, a lively faith, a deep spirituality, and a distinctive Christian attitude; he practiced heroic virtue, and his achievements were great, as evidenced by the fact that the Catholic Church has declared him Blessed. Many published biographical studies provide insight into the life of this holy man. ${ }^{1} \mathrm{Bl}$. Fr. Sopocko's rich legacy of

The following biographical works have been published: S. Strzelecki, Wkład księdza Michała Sopoćki w formację duchowieństwa, Bialystok 1983; M. Paszkiewicz, Ks. Michat Sopoćko 1888-1975, Bialystok 1987; H. Ciereszko, Stuga Boży ksiadz Michat Sopoćko, $1^{\text {st }}$ Edition, Bialystok 1955, $2^{\text {nd }}$ Edition, Bialystok 1998; H. Ciereszko, Droga świętości ks. Michała Sopoćki, WAM, Cracow 2002; 
writings, some of which have been translated into other languages, is of inestimable value.

The role that Fr. Sopocko played in the life and mission of St. FausBl. Michael Sopocko tina Kowalska and his efforts to spread the Divine Mercy apostolate are that which set him apart from other great figures in the Church. Fr. Sopocko's greatness, which stemmed from his faithfulness in his daily life and his heroic efforts to cooperate with God's grace, prepared him to take on the responsibility to serve as the confessior and spiritual director of a holy mystic and visionary and to help realize her mission and the Divine Mercy apostolate. He responded to God's call through his apostolic efforts. He patiently endured setbacks and sufferings while exercising unwavering trust in God's mercy, about which he preached, even though he did not live to see the fruits of his labors. His work in spreading the Divine Mercy apostolate is Fr. Sopocko's greatest achievement.

\section{Maturing in His Apostolate and His Motives}

In his own Diary, Fr. Sopocko admits that, when Sr. Faustina told him the truth about Divine Mercy, she inspired him to research, study, and contemplate this mystery. At the same time, he also confessed that he was unable to properly understand what Sr. Faustina told him about her interior experiences and what the work that God had entrusted to her meant in the beginning. For this reason, he listened to her more closely, pondered what she said, studied, sought the counsel of others, and, only after a few years, understood the greatness and value of the truth about God's mercy for the Christian life as well as the importance of spreading this message to the entire world. He also became convinced of the extreme importance of this truth in pastoral ministry as well as the spiritual fruits of worshiping Divine Mercy. ${ }^{2}$

H. Ciereszko, Ksiadz MichatSopoćko apostoł Miłosierdzia Bożego, WAM, Cracow 2004; H. Ciereszko, Życie i działalność księdza Michała Sopoćki (1888-1975). Petna biografia apostoła Miłosierdzia Bożego, $1^{\text {st }}$ Edition, WAM, Cracow 2006; H. Ciereszko, Życie i działalność błogosławionego Michała Sopoćki (1888-1975). Petna biografia apostoła Miłosierdzia Bożego, $2^{\text {nd }}$ Edition,WAM, Cracow 2013.

2 "There are truths that one knows and often hears and speaks about, but that one does not understand. That is how it was with me regarding the truth of Divine Mercy. I spoke about this truth so many times in my homilies and I repeated it in prayers-especially in the psalms-but I did not understand the meaning of this truth, nor did I penetrate its meaning - that it is the highest attribute of God's external activity. It was not until a simple Polish nun, Sr. Faustina, from the Congregation of the Sisters of Our Lady of Mercy briefly told me about her insights and repeated them frequently, thus inspiring me to do research, study, 
Bl. Michael Sopocko

Sr. Faustina's statements about Divine Mercy made it possible for Fr. Sopocko to discover more fully how God had mercifully guided him in his life. ${ }^{3}$ Her indications inspired him to study the Church's teaching on this mystery, which confirmed that mercy is God's highest attribute in his action toward his creatures. One can assume that Fr. Sopocko gradually encountered the mystery of God's mercy in his own soul. As the one who would promote the Divine Mercy apostolate, Fr. Sopocko himself had to discover what God's mercy is-he had to experience the grace of coming to know this mercy and its power and to discover the truth about the need for Christians to turn to God's mercy in their own spiritual and religious lives. There is no other way to explain his fervor in promoting this idea and devoting himself to this work. Through his profound apostolic zeal, his own personal growth in a life of faith, the deepening of his theological knowledge, and the continual enrichment of his pastoral practices, he was formed and prepared to be the Apostole of Divine Mercy. Sr. Faustina and her revelations were an inspiration for Fr. Sopocko, and they pushed him to persevere in his studies on the theology and spirit of the mystery of Divine Mercy. Ultimately, his own research efforts, which were supported by his prayer, were the source of his apostolic involvement. These studies opened him to that to which God was calling him. It was for this reason that Fr. Sopocko wrote the following in his Diary in 1938: "To trust in God's continued mercy, spread devotion to this mercy, among other things,

and think about this truth often. I cannot repeat-or rather capture-the details of our conversation, but rather only generally point out that at the beginning I did not really know what was going on. I listened, I did not believe what I heard, I reflected, I examined and questioned, and I sought the advice of others. It was not until a few years later that I understood the importance of this work and the greatness of this idea, and I found out for myself how effective this old and neglected, but also demanding and life-giving worship is for our time, which is in much need of renewal." (M. Sopoćko, Dziennik, $3^{\text {rd }}$ Edition, Bialystok 2015, pgs. 97-98.)

"Looking back on my childhood, I see one long train of manifestations of the immeasurable mercy of God, who permitted me to be born to godly Christian parents; who cared for me in my many illnesses; who protected me from certain death in accidents; who has saved me from eternal death so far despite the numerous and dangerous occasions [for it]. I owe my priestly vocation most of all to God's mercy-a vocation that I sensed quite early [in life]. It was his mercy that sustained my desire [to become a priest] despite so many obstacles, that led me through numerous experiences in which I would have surely fallen and died if the Creator had not had pity on me and sent me obvious help in advance. I have often clearly seen how this mercy withdrew its natural cooperation with human forces, to warn me and to pull me away from that which threatened my body or soul and to stir me to work and act in one way or another" (M. Sopoćko, Dziennik, Bialystok 2015, pgs. 100-101). 
and completely dedicate all of my thoughts, words, and actions [to it] without self-seeking will be, through the help of God's immeasurable mercy, the guiding principle for the rest of my life." 4

Fr. Sopocko's was prepared for his role in spreading the Divine Mercy apostolate over time, during which his confidence in the importance of the apostolate ever increased. As he came to recognize the significance of the truth about Divine Mercy in pastoral ministry, Fr. Sopocko-in his own intuition and devotion to pastoral ministry—noticed that the Divine Mercy apostolate and pastoral care are interdependent and connected in many ways. If the essence of pastoral ministry is to lead people to God, then what more can turn people to God than the truth that God is merciful? What more can change man than worshipping God in His mercy and imitating Him by performing works of mercy? In fact, as Fr. Sopocko stated, he himself began to discover how this truth had a beneficial influence on the faithful, especially those who experienced their own misery, weakness, and sin. As he witnessed how people converted; how their lives of faith deepened; and how their hope and trust in God strengthened, Fr. Sopocko became more and more convinced that teaching about Divine mercy was very fruitful. In this way, it became clear to him that both pastoral ministry and the Divine Mercy apostolate are inextricably linked. ${ }^{5}$

Another one of Fr. Sopocko's motives for being involved in and promoting Divine Mercy was that he discovered that it had its foundations in public revelation and in the teachings of the Church. For this reason, Fr. Sopocko did not even reveal Sr. Faustina's extraordinary experiences to anyone for many years,,nor did he consider her revelations as the basis of the apostolate. This is also why he often pointed out in his later statements that he did not connect the spreading of the message of Divine Mercy with Sr. Faustina's revelations in the sense that these revelations were the source and basis of the worship

\footnotetext{
M. Sopoćko, Dziennik, $3^{\text {rd }}$ Edition, Bialystok 2015, pg. 101.
}

5 Fr. Sopocko described the relationship between pastoral work and the apostolate of Divine Mercy in the following way: "Pastoral work is the work of the Church that concerns the salvation of souls. The subject of pastoral work is man who, after his earthly life, passes over to eternal life in a state of happiness, purification, or rejection depending on whether and to what extent he strove to love God during his life and at the moment of his death. Since love for God best arises, develops, and grows under the influence of one's knowledge and worship of God in his infinite mercy, pastoral care needs the role of the Most Merciful Savior, which is the personification of infinite Divine Mercy" (M. Sopoćko, Miłosierdzie Boga $w$ dzietach Jego, Paris 1967, pg. 173; $3^{\text {rd }}$ Edition, Wydawnictwo św. Jerzego, Bialystok 2017, pg. 204). 
Bl. Michael Sopocko

of Divine mercy. ${ }^{6}$ This does not mean, however, that Fr. Sopocko's involvement in the Divine Mercy apostolate, which differed from St. Faustina's involvement, was not the fulfillment of the call that was made manifest in St. Faustina's revelations. On the contrary, Jesus' command to celebrate Divine Mercy in His merciful image, to establish the Feast of Divine Mercy and the devotion to it, and to announce the truth about Divine Mercy could not be achieved better than through Fr. Sopocko's work to establish Divine Mercy's theological and biblical foundations. This was all the more necessary because, as a simple nun, Sr. Faustina could not fulfill these demands in the same way that Fr. Sopocko could as a priest, pastor, and theologian. Through her life and spiritual sacrifice, Sr. Faustina became the instrument through whom God admonished mankind to worship Him in His Divine Mercy, while Fr. Sopocko, as her spiritual director, was chosen by God to carry out this apostolic work through his external involvement and efforts, which were strengthened by his acceptance of the suffering that this involvement entailed.

\section{The Cooperator in and Continuator of St. Faustina's Mission}

Through her personal revelations and interior experiences, Sr. Faustina was called to spread Divine Mercy to the whole world. However, she also expected that her confessor help her in this endeavor, particularly by having the image of Merciful Jesus painted, establishing the Feast of Divine Mercy, and founding a religious congregation. As was shown above, after initially examining the authenticity of Sr. Faustina's apparitions and becoming convinced of the pastoral value of devotion to Divine Mercy, Fr. Sopocko took the necessary steps to fulfill Jesus' demands. At the same time, he also strove to explore the Church's teaching on Divine Mercy. At Sr. Faustina's insistence, Fr. Sopocko oversaw the painting of the image of the Merciful Jesus, and he published works on the truth about and worship of Divine Mercy as well as on the need for and meaning of the Feast of Divine Mercy. He oversaw the printing of the first copies of the Divine Mercy Chaplet, Novena, prayers, and the litanies, which he himself arranged based on the words that Jesus spoke to St. Faustina that she recorded in her

\footnotetext{
$6 \quad$ A copy of Fr. Sopocko's letter to the Archbishop of Cracow, which he wrote on May 19, 1966, can be found in the Archdiocese of Bialystok's Archive.
} 
diary. ${ }^{7}$ He appeared before bishops with a letter requesting that the Feast of Divine Mercy be established.

Fr. Sopocko's works, which were significant in and of themselves Bl. Michael Sopocko according to St. Faustina, were only the beginning of his efforts to spread devotion to and worship of Divine Mercy. Fr. Sopocko put a lot of personal effort into this work of God; unfortunately, however, the faithful did not readily receive his initial efforts. As a result, Fr. Sopocko experienced many minsunderstandings and difficulties, which were a source of great suffering for him. St. Faustina, who had already named Fr. Sopocko the Apostole of Divine Mercy, ${ }^{8}$ acknowledged that he too had received much light and help from God in this work. ${ }^{9}$ She perceived in him the one God had appointed to cooperate with her in this mission and to continue it after her death. In one of her letters to Fr. Sopocko from December 20, 1936, St. Faustina wrote:

... a lot has already been done in this matter. When I ponder these things, I am seized with holy amazement that you, Father, have already arranged so many things, which at the beginning seemed unthinkable because of the rising difficulties. I am hoping that nobody else but you, Father, will carry out the remaining matters. ${ }^{10}$

Similarly, in her Diary, she revealed that Fr. Sopocko was chosen to complete the Divine Mercy apostolate and that God would give him the strength to carry out this work despite opposition and difficulties. ${ }^{11}$ St. Faustina was very interested in Fr. Sopocko's activities (she often asked about them in her letters) and she knew about his undertakings. She highly valued and was very grateful to Fr. Sopocko for his efforts. ${ }^{12}$ One can infer the extent and significance of Fr. Sopocko's involvement from St. Faustina's statements in her letters to Fr. Sopocko. In another letter to Fr. Sopocko, Sr. Faustina shared:

Known to me are all your undertakings and intentions in the work of the Divine Mercy; I see how many souls already glorify this

$7 \quad$ Jezu ufam Tobie. Chrystus - Król Miłosierdzia, Cracow 1937.

8 The Letters of Saint Faustina Kowalska, Cracow: 'Misericordia' Publications, 2007, September 20, 1936, pg. 55. Hereafter abbreviated as The Letters. F. Kowalska, The Diary of St. Faustina Kowalska, Stockbridge Massachusetts: Marians of the Immaculate Conception, 2001, no. 1253. Hereafter abbreviated as Diary.

$9 \quad$ The Letters, May 6, 1937, pg. 95; December 20, 1936, pg. 72. Diary, 1253.

$10 \quad$ The Letters, December 20, 1936, pg. 73.

$11 \quad$ Diary, 422, 1252, 1253, 1401, 1472, 1586.

12 The Letters, December 20, 1936, pg. 73; April 11, 1937, pg. 84. 
Bl. Michael Sopocko incomprehensible mercy of God. My heart flutters with joy when I see the good that is effected in human souls through this work. ${ }^{13}$

Sr. Faustina expected that Fr. Sopocko would be externally involved in the matters related to the Divine Mercy apostolate, while she, on her part, supported him with her prayers and sacrifices. In almost every letter, Sr. Faustina assured Fr. Sopocko of her spiritual help, which was so important for this work:

"Following your suggestion, Father, with all my soul I direct my efforts towards this Feast in order to help you, Father, in this great, divine work through my prayer and whole-burnt offering of myself: I shall entreat God's blessing for you, dear Father, as regards this whole matter."14

As can be clearly seen, St. Faustina cooperated beautifully in the work of the apostolate; she participated more spiritually and interiorly, while Fr. Sopocko carried out much of the exterior apostolic work through the support of St. Faustina's prayers and sacrifices.

From the very beginning, Fr. Sopocko and Sr. Faustina encountered many difficulties in their work. They wrote about these experiences in their correspondence to each other. However, they both agreed that one always encounters obstacles in carrying out God's great works and that these efforts always require great sacrifices and entailed great sufferings, ${ }^{15}$ both of which they personally and frequently experienced. ${ }^{16}$ As she revealed in her correspondence, Sr. Faustina sympathized with Fr. Sopocko and prayed fervently for him when he experienced setbacks: "And now, as regards the issues and adversities which you, Father, are going through personally; it caused me much pain [to learn] that the truth is persecuted, but it often happens that one's personal sanctity proves to be a thorn in somebody's side. I prayed fervently for this matter..."17 In another letter she consoled him by telling him that those who are chosen by God experience difficulties, ${ }^{18}$ and uplifted him, saying "...big and noble hearts are always filled with ingratitude and bitterness." 19

Ibid, September 20, 1936, pgs. 55-56.

Ibid, May 6, 1937, pgs. 93-94.

Ibid, May 6, 1937, pg. 95; February 21, 1938, pg. 107; May 15, 1936, pg. 37; October 5, 1936, pg. 59; November 21, 1936, pgs. 70-71.

Ibid, February 21, 1938, pgs. 106-109; June 29, 1938, pg. 112.

Ibid, February 21, 1938, pg. 107.

Ibid, January 31, 1937, pg. 77.

Ibid, May 6, 1937, pg. 95. 
While Sr. Faustina and Fr. Sopocko both experienced difficulties and sufferings because of their efforts, they mutually supported and encouraged each other, especially through prayer. Sr. Faustina died Bl. Michael Sopocko long before Fr. Sopocko, so he was left with the great and difficult work of continuing the mission that they had begun together. In the final letter that she composed to Fr. Sopocko a few months before she died, Sr. Faustina wrote:

I am curious to know how things are with you, Father? Has your health improved? I asked God to keep you in good health for many years to come because this is necessary for this work. Oh Father, I cannot tell you how happy I am that the Divine Mercy is already being worshipped, in spite of all the adversities and human envy, in spite of Satan's anger and hatred. God's work will not suffer one bit of loss. The Lord God gave me to see His glory, which flows from this work, and this is only the beginning. My heart was amazed at the sight of this knowledge [...] And yet, in spite of the fact that God Himself is in charge of this work, we are obliged to do everything that is in our power in order to move it forward, even though our efforts might seem to be of no avail. However, God's work is built on them. ${ }^{20}$

These words are as if Sr. Faustina's final testament. They express what had already happened with regard to the mission of spreading the truth about and worship of Divine Mercy and the joy that it brought. They also indicate that much remained to be done, that God was guiding their efforts, and that He would realize his work. But, God needed their efforts along with the unavoidable sufferings they entailed. The fact that Sr. Faustina addressed these words to Fr. Sopocko reveals that she saw in him the one who would continue her mission.

As a very telling sign of the particular role that Fr. Sopocko would play along with Sr. Faustina in the work of the Divine Mercy apostolate is contained in a prophetic vision that St. Faustina had and recorded in her Diary:

May 8, [1938]. Today, I saw two enormous pillars implanted in the ground I had implanted one of them, and a certain person, S.M., the other. We had done so with unheard-of effort, much fatigue and difficulty. And when I had implanted the pillar, I myself wondered where such extraordinary strength had come from, and I recognized that I had not done this by my own strength, but with the power which came from above. These two pillars were close to each other, in the area of the image. And I saw the image, raised up very high and hanging from these two pillars. In an instant, there stood a large temple, supported both from within and from without, upon these two pillars.

Ibid, June 29, 1938, pgs. 112-113. 
Bl. Michael Sopocko

I saw a hand finishing the temple, but I did not see the person. There was a great multitude of people, inside and outside the temple, and the torrents issuing from the Compassionate Heart of Jesus were flowing down upon everyone. ${ }^{21}$

It seems that the initials "S.M." refer to none other than Fr. Sopocko. Since Sr. Faustina wrote other things like this about Fr. Sopocko, his apostolate, and his work, it is clear that what she wrote about the unheard of effort and fatigue pertain to Fr. Sopocko.

\section{An Outline of the Apostolate's Main Works}

Among Fr. Sopocko's achievements in his work to spread Divine Mercy, which justify his title as the Apostole of Divine Mercy, was his providential guidance of Sr. Faustina in her interior visions and revelations. Through his help, Sr. Faustina was able to verify the authenticity of her experiences. Because of his indications, she also recorded her experiences in her Diary. Thanks to Fr. Sopocko's indications, Sr. Faustina's Diary is widely available and continues to be an inexhaustible source through which individuals can explore the mystery of Divine Mercy. Fr. Sopocko's was also the one who had the first image of Jesus, the King of Mercy, painted according to Sr. Faustina's indications in Vilnius in 1934. In addition, Fr. Sopocko, who was inspired by Sr. Faustina's visions and, above all else, who himself had discovered the great value of the truth about Divine Mercy in his pastoral ministry, was the first individual to present the topic of Divine Mercy publicly. Even in 1936 he published an article dedicated to the topic of this truth, and he wrote about the worship of and a feast dedicated to Divine Mercy in a subsequent article..$^{22}$ At that time, he also approached the Polish bishops with a letter requesting that the Feast of Divine Mercy be established, and he approached the Primate of Poland, Cardinal A. Hlond about this issue. In 1939, he also went to Rome to see to this matter. Fr. Sopocko's work and the information that he obtained while performing it increased his awareness that it was first necessary to prepare the proper conditions into which to introduce the Feast of Divine Mercy. Therefore, he first taught and published articles about Divine Mercy, the meaning of the Feast Divine Mercy, and worship in

21

22
Diary, 1689.

Miłosierdzie Boże, "Wiadomości Archidiecezjalne Wileńskie" 10 (1936), pgs. 44-46, 104-106, 118-121, 134-137, 152-155, 167-170, 181-185; Miłosierdzie Boże. Studium teologiczno-praktyczne, Vilnius 1936; Myśli do kazań o Miłosierdziu Bożym, "Przegląd Homiletyczny" 14 (1936), pgs. 243-249; Idea Miłosierdzia Bożego w liturgii, Misterium Christi 8 (1937), pgs.102-116. 
order to awaken in the people a desire for this feast. His efforts were successful because, after reading about Divine Mercy, people began to request that such a feast be established. Fr. Sopocko then strove Bl. Michael Sopocko to convince the bishops to petition the Holy See for the feast, which they did. Fr. Sopocko's intuitive understanding of the truth of Divine Mercy as well as his substantiations and explanations for the establishment of the feast and spreading devotion to Divine Mercy, which he developed in the 1930s, served as the basis of ecclesiastical approval of the worship and establishment of the feast of Divine Mercy in this day and age.

Fr. Sopocko did not begin to teach directly about Divine Mercy and spread devotion to it until the Second World War. Having obtained approval from the Archdiocesan Curia of Vilnius, Fr. Sopocko began to distribute images of the Merciful Jesus along with prayers. He also gave homilies and conferences on this topic. He wrote a Latin treatise on Divine Mercy and the need to worship it, ${ }^{23}$ which he sent to bishops throughout the world by taking advantage of the migration of peoples that was taking place during the war. He also helped organize the foundation of a future religious order in Vilnius, which, in the spirit of the indications that St. Faustina recorded in her diary, would pray and serve the cause of Divine Mercy. Because of the atmosphere that the threats of war created, people sought God's help and rescue and were readily open to the Divine Mercy image and prayers that Fr. Sopocko shared with them. In turn, people shared the prayers and image with fellow refugees and exiles who went on to spread the Divine Mercy image and prayers far beyond Vilnius into Russia, Western Europe, and even America.

After the Second World War, Fr. Sopocko continued the apostolate and made efforts to obtain the Church authorities' approval of Divine Mercy until the end of his life. He tirelessly taught and researched the biblical, theological, and pastoral foundations for the truth and worship of Divine Mercy. His extensive and rich writings document his activity; he published a dozen or so books, dozens of articles, and numerous texts in manuscripts and typescripts..$^{24}$ Fr. Sopocko also strove

23 De Misericordia Dei deque eiusdem festo instituendo. Tractatus dogmaticus ac liturgicus, Vilnae 1940; De Misericordia Dei deque eiusdem festo instituendo. Tractatus dogmaticus ac liturgicus, Detroit 1943.

24 The major printed publications are: O święto Najmiłosierniejszego Zbawiciela, Poznan 1947; Miłosierdzie Boże nadzieja ludzkości, Wroclaw 1948; Kult Serca Jezusowego a kult Miłosierdzia Bożego, AK 48 (1948), pgs. 33-40; Poznajmy Boga $w$ Jego Mitosierdziu. Rozważania o mitosierdziu Bożym na tle litanii, Poznan 1949; Godzina święta i Nowenna o Miłosierdzie Boże nad światem, 
Bl. Michael Sopocko

to correct people's concept of Divine Mercy through the image of the Merciful Jesus. In 1954, Fr. Sopocko obtained the Conference of Polish Catholic Bishops' approval to commission the artist L. Slendzinski to paint an image of the Merciful Jesus that would serve as the ideal example Divine Mercy. Fr. Sopocko also helped to found the religious Congregation of the Sisters of the Merciful Jesus, which grew out of the Vilnius community. From the very beginning, Fr. Sopocko was the spiritual guide for this order of women; he wrote its first constitutions; and he oversaw the spiritual care of the religious congregation for the remainder of his life. He also helped to organize the Secular Institute of Divine Mercy, which had its roots in the Vilnius community. He tried to involve people in the apostolate in different ways, especially the sisters of the newly-formed religious community and secular institute, sisters from St. Faustina's religious community (which was the community from which the newer communities had arisen), priests, and laypeople who were interested in the devotion, whom he also tried to organize into a group that would perpetually worship Divine Mercy. Throughout the 1960-70s, Fr. Sopocko actively participated in academic conferences and symposia that were dedicated to the topic of the truth about Divine Mercy. He continually presented matters pertaining to the worship of Divine Mercy and the establishment of the Feast of Divine Mercy by addressing and appealing to the Primate of Poland and the Polish Conference of Bishops through letters, petitions, and personal meetings. When necessary, he explained, presented arguments, and defended the devotion. In addition, he experienced many painful difficulties and misunderstandings on the part of others who reacted negatively to the spontaneous development of the devotion.

Poznan-Warsaw-Lublin 1949; Wielbijmy Boga w Jego Miłosierdziu, Franciscan Publishers, Pulaski, Wisconsin 1958; Miłosierdzie Boga w dziełach Jego, vol. 1, London 1959, $2^{\text {nd }}$ Edition, Bialystok 2008, $3^{\text {rd }}$ Edition, Bialystok 2017; Wielbijmy Boga w Jego Miłosierdziu. Modlitewnik, Stockbridge Mass. 1961; Nowenna i inne modlitwy do Miłosierdzia Bożego, Stockbridge Mass. 1961; M. Sopoćko, J. Chróściechowski,Divine Mercy Devotions and Prayers, $1^{\text {st }}$ Edition, Stockbridge Mass. 1961; Miłosierdzie Boga w dziełach Jego, vol. 2, Rome - Paris - London $1962,2^{\text {nd }}$ Edition, Białystok 2008, $3^{\text {rd }}$ Edition, Białystok 2017; Miłosierdzie Boga $w$ dziełach Jego, vol. 3. Rome-Paris-London 1962, $2^{\text {nd }}$ Edition, Bialystok 2008, $3^{\text {rd }}$ Edition, Bialystok 2017; The Mercy of God in his Works, vol. 1, Hereford et Stockbridge Mass. 1962; Gods is mercy. Meditations on God's most consoling attribute, Stockbridge Mass. 1965; Miłosierdzie Boga w dzietach Jego, vol. 4, Paris 1967, $3^{\text {rd }}$ Edition, Bialystok 2017; The Mercy of God in his Works, vol. 2, Stockbridge Mass. 1968; vol. 3, Stockbridge Mass. 1968; M. Sopoćko, J. Chróściechowski, Domine, miserere nobis! De Christo Sajvatore Miserenrissimo adorando et de sua misericordia generi humano imploranda, Fawley Court, Henley-on-Thames, Oxon 1968. 
Church authorities distanced themselves from Fr. Sopocko, and even local bishops forbid the spreading of the devotion in the forms mentioned in Sr. Faustina's diary. In fact, even the Holy See prohibited the Bl. Michael Sopocko devotions in 1959, even though Fr. Sopocko's activities were in accord with the spirit of the Church's thought.

Fr. Sopocko's apostolic efforts are undoubtedly an important contribution to the work of spreading and popularizing the devotion to Divine Mercy. It is because of his efforts that the Church in the modern day approved of worship of Divine Mercy. St. Faustina's testimonies and messages based on her interior inspirations reveal the role and truth about how God chose Fr. Sopocko to carry out the apostolic work described above. In her Diary, St. Faustina includes this testimony, among many others, that strongly confirms the inestimable role that Fr. Sopocko was meant from all time to play in God's plan:

So I asked Jesus to give these graces to someone else, because I did not know how to make use of them and was only wasting them. 'Jesus, have mercy on me; do not entrust such great things to me, as You see that I am a bit of dust and completely inept. But the goodness of Jesus is infinite; He had promised me visible help here on earth, and a little while later I received it in Vilnius, in the person of Father Sopocko. I had already known him before coming to Vilnius, thanks to an interior vision. One day I saw him in our chapel between the altar and the confessional and suddenly heard a voice in my soul say, This is the visible help for you on earth. He will help you carry out My will on earth. ${ }^{25}$

\section{BŁOGOSŁAWIONY MICHAŁ SOPOĆKO - APOSTOŁ BOŻEGO MIŁOSIERDZIA}

W historii upowszechnienia się w naszych czasach kultu Miłosierdzia Bożego wyjątkowe miejsce zajmuje i taką też rolę odegrał ks. Michał Sopoćko. Wskazany św. Faustynie w objawieniach, stał się jej spowiednikiem i kierownikiem duchowym oraz otworzył się na apostolstwo Miłosierdzia Bożego. Siostra widziała w nim współrealizatora i kontynuatora powierzonej jej misji głoszenia prawdy Miłosierdzia Bożego i szerzenia kultu. Przyczynił się do powstania Dzienniczka, doprowadził do namalowania w Wilnie w 1934 r. pierwszego wizerunku Jezusa Miłosiernego. Pierwszy zaczął pisać o Miłosierdziu Bożym i kulcie oraz wydrukował już w 1937 r. tekst Koronki i Nowenny do Miłosierdzia Bożego. Zabiegał o ustanowienie Święta Miłosierdzia Bożego i zatwierdzenie kultu przez władze 
Bl. Michael Sopocko

kościelne. Niestrudzenie nauczał o Miłosierdziu Bożym i wydał szereg prac poświęconych tej prawdzie oraz nabożeństwu do Miłosierdzia Bożego. Jego poświęcenie, znoszone przeciwności, gorliwość apostolska są niewątpliwie istotnym wkładem w apostolstwo Miłosierdzia Bożego w naszych czasach i nie mogą nie mieć znaczenia dla upowszechnienia się kultu Miłosierdzia Bożego w Polsce i świecie.

Słowa kluczowe: miłosierdzie Boże, apostolstwo miłosierdzia Bożego, kult Miłosierdzia Bożego, św. Faustyna Kowalska, bł. Michał Sopoćko.

\section{Bibliography:}

1. Ciereszko H., Droga świętości ks. Michała Sopoćki, WAM, Cracow 2002.

2. Ciereszko H., Ksiądz Michat Sopoćko apostot Miłosierdzia Bożego, WAM, Cracow 2004.

3. Ciereszko H., Stuga Boży ksiadz Michat Sopoćko, $1^{\text {st }}$ Edition, Bialystok $1955,2^{\text {nd }}$ Edition, Bialystok 1998.

4. Ciereszko H., Życie i działalność błogostawionego Michała Sopoćki (18881975). Petna biografia apostoła Miłosierdzia Bożego, $2^{\text {nd }}$ Edition,WAM, Cracow 2013.

5. Ciereszko H., Życie i działalność księdza Michała Sopoćki (1888-1975). Petna biografia apostota Mitosierdzia Bożego, $1^{\text {st }}$ Edition, WAM, Cracow 2006.

6. Kowalska F., The Diary of St. Faustina Kowalska, Stockbridge Massachusetts: Marians of the Immaculate Conception, 2001.

7. Sopoćko M., Chróściechowski J., Divine Mercy Devotions and Prayers, $1^{\text {st }}$ Edition, Stockbridge Mass. 1961.

8. Sopoćko M., Chróściechowski J., Domine, miserere nobis! De Christo Sajvatore Miserenrissimo adorando et de sua misericordia generi humano imploranda, Fawley Court, Henley-on-Thames, Oxon 1968.

9. Sopoćko M., Dziennik, $3^{\text {rd }}$ Edition, Bialystok 2015.)

10. Sopoćko M., Gods is mercy. Meditations on God's most consoling attribute, Stockbridge Mass. 1965.

11. Sopoćko M., Godzina święta i Nowenna o Miłosierdzie Boże nad światem, Poznan - Warsaw - Lublin 1949.

12. Sopoćko M., Idea Miłosierdzia Bożego w liturgii, "Misterium Christi" 8 (1937), pgs. 102-116.

13. Sopoćko M., Jezu ufam Tobie. Chrystus - Król Miłosierdzia, Cracow 1937.

14. Sopoćko M., Kult Serca Jezusowego a kult Miłosierdzia Bożego, AK 48 (1948), pgs. 33-40.

15. Sopoćko M., Miłosierdzie Boga w dziełach Jego, Paris 1967, pg. 173.

16. Sopoćko M., Miłosierdzie Boga $w$ dziełach Jego, vol. 1, London 1959, $2^{\text {nd }}$ Edition, Bialystok 2008, $3^{\text {rd }}$ Edition, Bialystok 2017.

17. Sopoćko M., Mitosierdzie Boga $w$ dziełach Jego, vol. 4, Paris 1967, $3^{\text {rd }}$ Edition, Bialystok 2017. 
18. Sopoćko M., Miłosierdzie Boże, "Wiadomości Archidiecezjalne Wileńskie" 10 (1936), pgs. 44-46, 104-10;

19. Sopoćko M., Miłosierdzie Boże. Studium teologiczno-praktyczne, Vilnius Bl. Michael 1936.

20. Sopoćko M., Mitosierdzie Boże nadzieja ludzkości, Wroclaw 1948.

21. Sopoćko M., Myśli do kazań o Mitosierdziu Bożym, "Przegląd Homiletyczny" 14 91936), pgs. 243-249

22. Sopoćko M., Nowenna i inne modlitwy do Mitosierdzia Bożego, Stockbridge Mass. 1961.

23. Sopoćko M., O święto Najmiłosierniejszego Zbawiciela, Poznan 1947.

24. Sopoćko M., Poznajmy Boga w Jego Miłosierdziu. Rozważania o miłosierdziu Bożym na tle litanii, Poznan 1949.

25. Sopoćko M., The Mercy of God in his Works, vol. 1, Hereford et Stockbridge Mass. 1962.

26. Sopoćko M., The Mercy of God in his Works, vol. 2, Stockbridge Mass. 1968; vol. 3, Stockbridge Mass. 1968.

27. Sopoćko M., Wielbijmy Boga w Jego Miłosierdziu, Franciscan Publishers, Pulaski, Wisconsin 1958.

28. Sopoćko M., Wielbijmy Boga w Jego Mitosierdziu. Modlitewnik, Stockbridge Mass. 1961.

29. Strzelecki S., Wkład księdza Michała Sopoćki w formację duchowieństwa, Bialystok 1983; M. Paszkiewicz, Ks. Michat Sopoćko 1888-1975, Bialystok 1987.

30. The Letters of Saint Faustina Kowalska, Cracow: 'Misericordia' Publications, 2007. 